\title{
Spatial distribution of construction firms in Istanbul
}

\author{
Turgay Kerem Koramaz* \\ Vedia Dökmeci** (D)
}

\begin{abstract}
In the restructuring of the cities today, economic growth and its reflective trend multicentred, urban development pattern made business enterprises shifted its locational choice in a decentralized way. As the focus of this paper, construction firms expended their market areas as well. The present study investigates the spatial distribution of construction firms according to the variables of socio-economic characteristics of districts and total construction sizes within the concept of multi-centre development in Istanbul. The paper describes the growth of the city and the construction firms through time according to the concentric zones and districts, firstly. Then descriptive figures and results of regression analysis are given by taking the number of construction firms as dependent variable and population, income per capita, average household size and amount of construction activity as the independent variables. Main hypothesis of this paper is that socio-economic indicators and total size of construction in building permits can explain the variance of number of construction firms in Istanbul district. Overall results from the multiple regression model indicate that the role of socio-economic indicators and total size of construction in building permits on the distribution of construction firms is proved on a large scale in the study. The spatial distribution of the construction firms has been figured out that the subcentral, peripheral districts of Istanbul have sustained the significant role in a way that responds to the construction supply, and housing sub-markets. However, the intense construction trends in the periphery reveal a fact that these firms preserve the location of their management offices in the sub-centre with relatively higher economic attraction, in central districts.
\end{abstract}

Keywords: construction firms, location, Istanbul.

\section{Introduction}

During the last half-century, rapid population growth resulted in urban sprawl (Terzi and Bolen, 2009), restructuring of the city according to new technology and economic development and multicentre development (Dokmeci and Berkoz, 1994) and increased construction sector tremendously as well as the number of construction firms. After 1980s, the largest construction companies expanded their market areas even into the Middle Eastern and North African markets (Kaynak and Dalgic, 1992; Duman et al. (2018). The present study investigates the spatial distribution of construction firms according to the variables of socio-economic characteristics of districts and total construction sizes within the concept of multi-centre development in Istanbul. 
In few countries, there are some studies, which investigate the decentralization of sub-sectors from the centre of cities. A pivotal and comprehensive study that was done for central Seoul, Korea by Nahm (1999) illustrates the transformation of business centre as a result of large scale urban renewal projects in the 1990s. According to the results of the study, the ratio of movement of construction firms from CBD to non-CBD (40\%) is higher than their movement intra-CBD (36\%) and non-CBD to $\mathrm{CBD}(4 \%)$ and non-CBD to non-CBD (8\%). $12 \%$ of the construction firms did not change their location in central Seoul, Korea.

Another study by Mazzarol and Choo (2003) deals with the factors influencing location decisions of small firms. According to their findings, locations of $34 \%$ of small firms were influenced by the proximity to customers. The paper by Maoh and Kanaroglou (2007) provides an empirical framework to illustrate the geographical clustering of firms in the City of Hamilton in Ontario, Canada. According to their results, most of the firms are decentralizing i.e. the number of construction firms decreased from 6\% to 4\% between 1990 and 1997. By Said et al. (2015) a survey was conducted all over the Peninsula of Malaysia about the construction firms. The results show that the majority of the companies were located in three major cities, i.e. 36 companies (11.3\%) were located in Penang (a north-eastern federal state), 60 companies (18.8\%) were located in Selangor (neighbouring federal state of Kuala Lumpur), and 92 companies (28.8\%) were located in Kuala Lumpur capital city and an individual federal territory of Malaysia. However, the operation offices might be different from the registered address due to the location of projects and other technical reasons. The paper by Adams et al. (2012) argues that UK speculative house builders rely more on networks than markets to source land and that structure those networks to enhance their own competitive positions. In addition, according to the economic study of London by Dunning and Morgan (2013) construction employment is $1.6 \%$ in the city of London and $4.9 \%$ in other districts of London, which represent decentralization. Thus, despite of the importance of construction sector for economic development (Chia et al., 2014); the review of the literature reveals that there is not much research on the subject at the local level. In order to disclose the case of local level, the present study investigates the spatial distribution of construction companies according to the characteristics of districts such as population, income per capita and amount of construction by the use of multiple regression analysis in Istanbul. Main hypothesis of this paper is that socio-economic indicators and total size of construction in building permits can explain the variance of number of construction firms in Istanbul district.

The organization of the paper is as follows: the growth of the city and the construction companies through time according to the concentric zones and districts are given in the second section. In the third section, aforementioned variables are given with descriptive figures and regression analysis by taking the number of firms as dependent variables and population, income per capita, average household size and amount of construction activity as the independent variables. The final section is devoted to a conclusion and suggestions for further research.

\section{Background: Construction Firms in Istanbul}

During the last two decades, Istanbul's population increased from 11,08 million in 2000, to 15,62 million in 2019. Globalization, closing down the government factories, and relaxation of restrictions on the agricultural imports fuelled the inter-provincial migration caused the rapid growth of Istanbul (Yazgi et al., 2014). Urban sprawl (Terzi and Bolen, 2009) with squatter development, gated towns in the periphery and multi-centre development (Dokmeci and Berkoz, 1994; Berkoz, 2000; Berkoz and Turk, 2008), government's large urban regeneration projects (Karaman, 2008; Kuyucu, et al., 2010), relaxation of density restrictions increased construction and thus growing construction sector as well as the number of construction companies at city wide. While the location of construction companies were first mostly in the central districts, further they followed the construction activity at the metropolitan level as the city expended. Decentralization of construction firms has gained a similar trend with similar studies in Ontario, Canada (Maoh and Kanaroglou, 2007) and London, England (Dunning and Morgan, 2013). 
During the period of 2007-2019, the number of construction companies registered at the Istanbul Chamber of Commerce, increased from 893 to 1,849. In the same period, investigation of the spatial distribution of construction companies according to the concentric rings as already described in Dokmeci and Berkoz (1994) revealed that the ratio of construction companies decreased from $6.4 \%$ to $2.3 \%$ in the core area, from $45.6 \%$ to $33.8 \%$ in the intermediate zone and increased from $48 \%$ to $63.9 \%$ in the periphery. These results strongly illustrate the rapid growth of peripheral districts and thus demand for housing.

In 2007, distribution of construction companies according to the districts illustrate that Sisli which is in European side of intermediate zone and new CBD, had the highest number of construction companies (140) due to need for construction many modern office buildings as a result of globalization. On the other hand, in 2019, in Kadikoy which is in the Asian side of the intermediate zone had the highest number of construction companies (234). The highest demand to live in this district (Hurriyet News, 2018) and the relaxation of density regulations by the Municipal Government fuelled the construction of high-rise housing as well as the number of construction companies. Thus, the urban growth of this district is the result of market forces as well as the Municipal Government policy. There are two reasons for attracting the highest amount of construction activity to this district: The first one, this district is the most preferable one due to quality of life (Dokmeci and Berkoz, 2000): attractive shopping streets, seashore amenities and housing in the gardens, educated people, cultural advantages due to upper class historical background. The second one: the construction of large urban transformation projects in the squatter neighbourhoods of this district to instigate a process of property transfer to stronger actors by up grading and beautification of their environment and increasing real estate values, and displacement of urban poor.

During the study period it is also observed that the concentration of construction companies at the sub-centres was critical due to large amount of construction such as in Atasehir (140) for construction of a business centre in a new town and high-rise housing. In Besiktas (from 70 in 2007 to 108 in 2019), the catalyst for this growth is building modern office buildings in order to answer to the growing demand for offices due to globalization and lately becoming a transportation hub, while in Umraniye (10 to 112 in the same period, given above) for restructuring of its squatter areas due to increased accessibility as a result of being at the intersection of peripheral highways. Similarly, the number of construction companies increased in the centres of the districts along the Marmara Sea shores with restructured large squatter areas such as in Maltepe from 29 to 99, in Kartal from 25-84 and in Pendik from 9 to 41 (Ozus, et al.2007). In the western part of the city, in the centres of the districts with large, restructured squatter areas, the number of construction firms increased such as in Kucukcekmece from 28 to 52, Esenyurt from 4 to 59 and Basaksehir from 1 to 43. The number of construction firms increased in the centres of historical districts, which have locational competitive advantage and seashore amenities, due to revitalization of their old buildings such as in Uskudar from 25 to 99 and in Fatih from 15 to 37 . The number of construction firms also increased from 12 to 53 in the centre of Sariyer District, which is located along the Bosphorus seashores due to construction of gated towns with the effect of globalization (Baycan-Levent and Gulumser, 2012).

The results of the analysis of the distribution of construction firms between 2007 and 2019 reveal that the location gravity was switched from the European side to the Asian side due to having larger open spaces and relaxing density requirements, and decentralization toward the peripheral centres of the metropolitan area. This trend is the result of market forces and the Municipal Government policies, which is within the concept of the case in China (Yue et al., 2010), and Seoul, Korea (Nahm, 1999), evidences of which are also highlighted with key economic and construction sector indicators in their correspondences in Turkey case (Alkay, et. all, 2018). Then this study investigates the relationships between the number of construction firms and the characteristics of districts by the use of multiple regression analysis in a more comprehensive way. 


\section{Data and Results: Multivariate Findings from Spatial Distribution of Construction Firms in Istanbul}

In this paper, number of construction firm in district level, in Istanbul is used as the dependent variable, data of which is gathered from Istanbul Chamber of Commerce, Web Portal with the records of 2019. There are a total of 1849 construction companies in the city, which has at least one construction company in 38 districts. Adalar, which has strict construction permissions and registered natural and urban conservation sites, has no construction firm, officially enrolled in Istanbul Chamber of Commerce. Sile, which is supposed to have similar barriers for constructions and conservation status, has the least number of construction firms among districts of Istanbul. Besides, Bayrampasa, Sultanbeyli and Catalca are the districts, which have less than 10 construction companies in-between their jurisdictions. When defining the multi-centred development pattern in the spatial distribution of construction firms, 3.73\% of these firms are located in core area (Fatih and Beyoglu); 32.83\% are located in the intermediate zone (Bayrampasa, Besiktas, Eyup, Kadikoy, Sisli, Uskudar, and Zeytinburnu); and $63.44 \%$ in the periphery. Kadıköy, which is one of the most populated central district in Istanbul and most critical spot for recent urban regeneration programs in Istanbul and even in Turkey, has the highest number of construction firms, as 234 . Other districts following Kadikoy in these numbers are Atasehir with 141 firms; Şişli with 115 firms; Umraniye with 112 firms; Besiktas with 108 firms and Uskudar and Maltepe with 99 firms each.

As the most crucial independent variable in this paper, construction permits' size in sqm is assumed to be correlated with number of construction firms. This variable is gathered from National Statistical Office's yearly-published data on construction statistics, which are compiled of entire construction permits submitted to the municipalities. These statistics determine the total number of buildings, quantities on size, and use categories, such as residential, commercial, etc. In the spatial distribution of total construction sizes in building permits, $2.77 \%$ of construction permits are registered in core area; $21.14 \%$ are registered in the intermediate zone; and $76.09 \%$ in the periphery. When associating these figures with spatial distribution of construction firms in Istanbul, differences between operation offices of the construction zones and registered address of headquarters is evident especially in peripheral districts, where total construction size in building permits are higher than the central districts but, fewer construction firms. This finding is entirely in reverse type in intermediate zone, where there is less total construction size in building permits in central district but higher number of construction firms. This bipolar opposition between intermediate and peripheral districts indicate the significance of sub-central districts in the economic pattern of the metropolitan city of Istanbul.

Only one of the three top districts with more construction firms, Kadikoy, as a district in intermediate zone, has relatively higher construction size, submitted in the relevant year. As indicated by Dokmeci and Berkoz (2000), the district of Kadikoy has sustained its economic attraction in real estate market with inhabitants of high socio-economic status. Basaksehir, Arnavutkoy and Pendik districts, also have the highest ranks on construction size in building permits in 2019 more than 700 thousand sqm. These districts are the peripheral districts the first two leading ones are in the European side and the third in Anatolian side. While associating these figures on increasing housing supply for middle and middle-high income households, these districts have a crucial role on urban sprawl of metropolitan development of Istanbul and relatively higher rental return in the periphery (Hepsen and Vatansever, 2012). Besides, Atasehir and Sisli are the districts, which have less construction sizes in building permits, and lower than the median value of the variable. On the contrary, Sultanbeyli district, with only 7 construction firms, official address of which are located in the district, has more construction size in building permits than the median value of the independent variable. Central district as Fatih, neighbouring ones as Bayrampasa,Güngören, and furthest peripheral districts as Sile and Catalca with least number of construction firms have relatively less construction size in the building permits. Peripheral districts where building codes are strictly prohibiting new development with natural conservation status and ecological values (Sile and Catalca); and central and neighbouring districts (Fatih, Gungoren, 
and Bayrampasa), which have already fulfilled their development capacity and new construction may not be possible, (Figure 1).

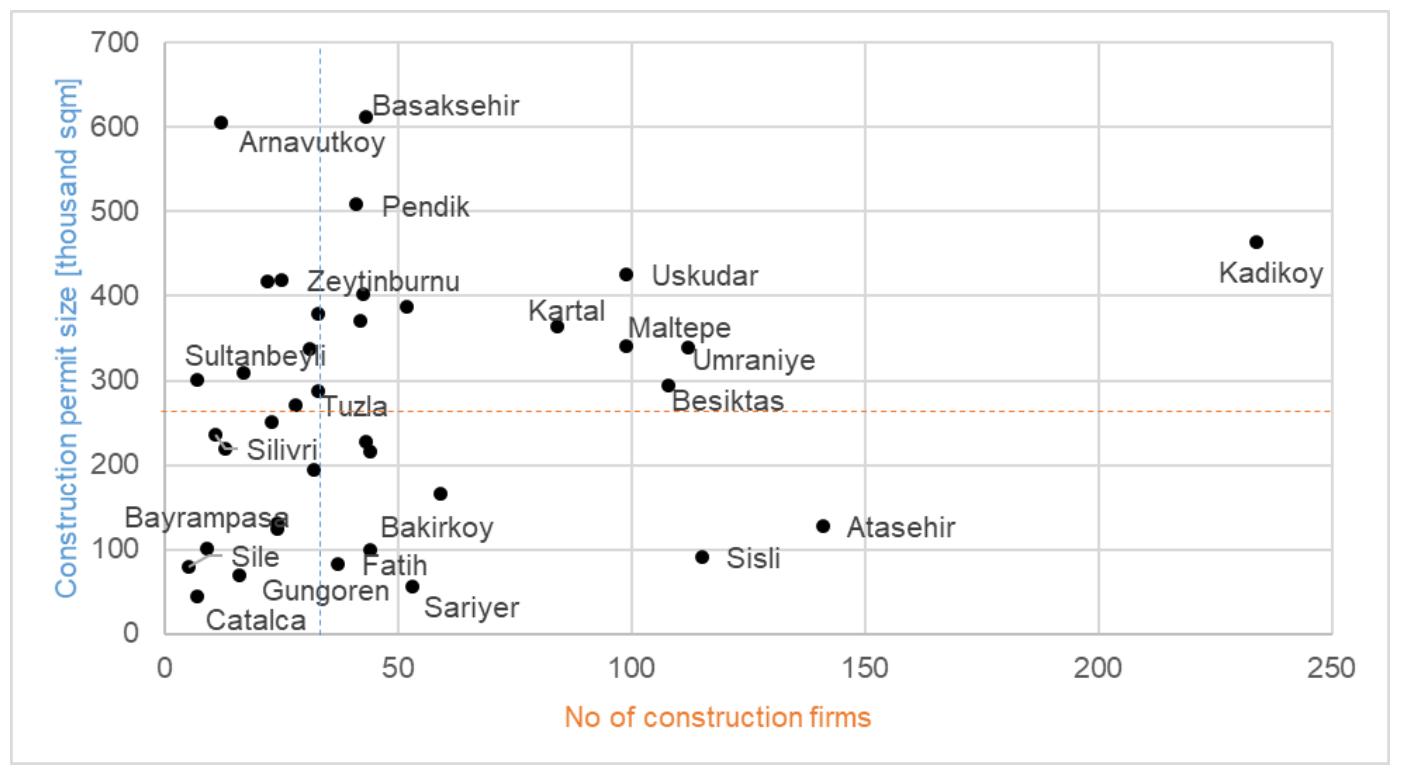

Page | 346

Figure 1 Association between total construction size in building permits and number of construction firms in districts, 2019

Independent variables in this paper are formulated as population size in 2019 (x1), gathered from Address Based Population Registration System, Turkish Statistical Institute (TUIK); annual total construction size in building permit (x2), from building statistics in 2019 (TUIK); average yearly income (x3) from Mahallem Istanbul Project (Seker et. all, 2017); and average household size (x4) from District-Based Average Household Size in 2018 (Istanbul Metropolitan Municipality, Open Data Portal, 2018). Descriptive figures on these variables are given in Table 1, below.

Table 1 Descriptive figures on dependent and independent variables

\begin{tabular}{|c|c|c|c|c|c|c|}
\hline & Variables & mean & std.dev. & median & $\min$. & $\max$. \\
\hline & No of construction firms & 48.66 & 46.44 & $\begin{array}{l}33 \\
\text { Sancaktepe Esenler }\end{array}$ & $\begin{array}{l}5 \\
\text { Sile }\end{array}$ & $\begin{array}{l}234 \\
\text { Kadikoy }\end{array}$ \\
\hline $\mathrm{x} 1$ & Population size [1000 people] & 407.99 & 197.38 & 412.80 & $\begin{array}{l}37.69 \\
\text { Sile }\end{array}$ & $\begin{array}{l}954.58 \\
\text { Esenyurt }\end{array}$ \\
\hline$x 2$ & Construction permit size [1000 sqm] & 262.12 & 156.25 & 260.69 & $\begin{array}{l}8.79 \\
\text { Beykoz }\end{array}$ & $\begin{array}{l}613.19 \\
\text { Basaksehir }\end{array}$ \\
\hline x3 & Average yearly income [1000 TL] & 52.49 & 25.09 & 43.84 & $\begin{array}{l}24.36 \\
\text { Arnavutkoy }\end{array}$ & $\begin{array}{l}126.72 \\
\text { Besiktas }\end{array}$ \\
\hline $\mathrm{x} 4$ & Average household size & 3.35 & 0.43 & 3.34 & $\begin{array}{l}2.47 \\
\text { Besiktas }\end{array}$ & $\begin{array}{l}.32 \\
\text { Sultanbeyli }\end{array}$ \\
\hline
\end{tabular}

Total population of Istanbul Metropolitan Municipality was 15.62 million in 2019, districts' population of which range from 37,692 (for Sile) and to 954,579 (for Esenyurt). Considering total population per construction firm, central districts like Besiktas, Kadikoy, Sisli and Atasehir has more firms than the rest of districts (respectively with the figures of 1,691.19; 2,062.88; 2,433.19; and $3,014.85$ person per a construction firm). This figure is higher than 30,000 person per a construction firm in Sultanbeyli, Sultangazi and Bayrampasa districts. 
When considering the total number of construction-based enterprises in Turkey, which comprises of economic activities such as development of entire construction and infrastructure projects, including installation of mechanical, electrical, plumbing services, telecommunication network, maintenance and repair of the buildings, there are more enterprises than construction firms, which are enrolled in Istanbul Chamber of Commerce. Basic indicators by economic activity statistics (2019) reveal that there were 121,494 construction-based enterprises in Turkey. Total population per construction enterprise in Turkey presents the figure as 681.88 , which is harshly higher than entire districts of Istanbul. This figure for Istanbul depict that there were 67,795 enterprises and 228.92 person per a construction enterprises (Business Demography, 2019). It is evident from being the leading city in construction sector; Istanbul has nearly five times more construction enterprises than the rest of the country. Since there is a significant disparity between economic enterprises in construction sectors by TUIK and Istanbul Chamber of Commerce, rate of construction firms' enrolment into Istanbul Chamber of Commerce is considerably low as a data limitation of this paper. This rate used in this paper, for Istanbul was gathered by Istanbul Chamber of Commerce as 8,393.33.

As the most critical indicators for social economic development rates, average yearly income and household size are used in the paper, for comprehending this development trend among the districts of Istanbul. Average household size of Turkey was 3.4 and of Istanbul 3.3 in 2019. 22 districts with more than 10 million population in sum, have relatively higher rates for this indicator than the rest of the districts, and these 22 districts holds only the $39.5 \%$ of the entire construction firm in Istanbul. Average yearly income for Istanbul was 51,691 TL in 2019. 24 districts with more than 10 million population in sum have relatively higher rates for this indicator as nearly similar as average household size indicator in Istanbul. These 24 districts also hold only 752 construction firms with the rate of $40.7 \%$ of the entire construction firm in Istanbul. It is obvious that districts with lower household size and higher income rates have relatively more construction firms, as reflected with the most significant socio-economic development indicators.

Multiple regression model is applied within the set of variables, given above that are assumed to have influence on number and distribution of construction firms, enrolled into Istanbul Chamber of Commerce. For the model, coefficient estimates and their standard errors with statistical diagnosis are reported in Table 2. As the result of ordinary least square (OLS) regression model R2 is 0.707 and adjusted $R 2$ is 0.672 , statistics of which is considered high. As the main hypothesis of this paper stated, socio-economic indicators and total size of construction in building permits can explain the variance of number of construction firms in Istanbul districts. This hypothesis is proved within R2 statistics, obtained form the regression model $(p=0.000$ and $F$ value $=19.943$ ), where entire variables in the model contribute with significant effect on the variance of number of the construction firms in Istanbul districts.

Table 2 Regression model results on the assumption of spatial distribution of construction firms in Istanbul

\begin{tabular}{|c|c|c|c|c|c|c|c|}
\hline \multirow[b]{2}{*}{ Model } & \multicolumn{2}{|c|}{ unstandardized coefficients } & \multirow{2}{*}{$\begin{array}{l}\text { st. coef. } \\
\text { Beta }\end{array}$} & \multirow{2}{*}{$\mathrm{t}$} & \multirow{2}{*}{ Sig. } & \multicolumn{2}{|c|}{ Collinearity Statistics } \\
\hline & ß & std. error & & & & tolerance & VIF \\
\hline x1 Population size [thousand people] & 0.097 & 0.025 & 0.41 & 3.826 & 0.001 & 0.771 & 1.298 \\
\hline x3 Average yearly income [thousand TL] & 0.886 & 0.25 & 0.479 & 3.548 & 0.001 & 0.487 & 2.054 \\
\hline x4 Average household size & -44.839 & 16.195 & -0.417 & -2.769 & 0.009 & 0.39 & 2.564 \\
\hline
\end{tabular}

Dependent variable is number of construction firms in districts.

As one of the strongest socio-economic development indicators in the explanation of number of construction firms in Istanbul districts, average yearly income has a coefficient of $0.886 p=$ 
0.001). Regression model estimates one unit $(1,000 \mathrm{TL})$ rise in income variable to contribute a direct increase in the number of construction firm in 0.886 unit. As the other socio-economic indicator average household size has a coefficient value of $-44.839(p=0.009)$, where one unit (one person) rise in household size variable suggests a decrease in the number of construction firm in 44.8 unit. As depicted in the descriptive figures of the data, socio-economic indicators hold a significant effect on the variance of construction firm numbers in Istanbul.

As total construction sizes in the building permits have a statistically significant effect on the emergence of construction firms in Istanbul, this study reveals the significance of supply on construction sector. As the coefficient of this variable $(x 2)$ is $0.07(p=0.031)$, regression model estimates one unit $(1,000 \mathrm{sqm})$ rise in construction size in building permits variable to contribute a direct increase in the number of construction firm in 0.07 unit. This finding proves the internal impact of the construction sector in the establishment of businesses that choose to take an active role in and benefit from the business organizations (Noel and Luckett, 2014), which can be defined as being enrolled within the chamber of commerce.

As identifying the spatial distribution, which reflect the population distribution as well, population size variable is also a significant variable in the contribution of variance of construction firm numbers in the districts. Regression model estimates ten unit $(10,000$ person) rise in population variable to contribute a direct increase in the number of construction firm in 0.97 unit. In particular, the districts with more population imply the higher rate of urban functions and services in the spatial distribution. This result is significant in the majority of studies, investigating the locational distribution of services or urban uses with population effect (Dokmeci and Berkoz, 2000; Ozus, 2009).

After investigating the estimated variance of the dependent variable, values residuals are tested within the consistency of multiple regression analysis. Difference between the actual number of construction firms in the districts and their estimated values in district level is calculated. Since the data used in this paper has limited number of variables, as a data limitation, surely not all of possible predictors are included in the regression model. A further residual analysis is performed in order to validate performance of the model with the standardized residuals, derived from the regression model. In 31 districts, covering 1,108 construction firms (nearly $60 \%$ of the entire firms in Istanbul) have residuals range from -1 to +1 , which indicate a validity of the model. Only seven districts are further away from these ranges up to 3.00 for Kadikoy and -1.88 for Bakirkoy.

The districts of Kadikoy, Atasehir, Umraniye, and Esenyurt with positive residuals in the regression model (respectively as $+3.00,+2.07,+1.94$, and +1.25 ), actually underestimate the effect of independent variables in the variance of number of construction firms. It can be interpreted that the construction firms in these districts have varying reasons beyond the variables used in the model, the prospective predictors of the location choice. As the most significant case for comprehensive urban regeneration projects by the law of 6306 (Turk, et. all, 2020), Kadikoy, Atasehir and Umraniye share a critical power in both area-based and property-based types of renewal programs in Anatolian side of Istanbul, Esenyurt in European side, particularly in areabased renewal programs. On the contrary, Basaksehir, Besiktas, and Bakirkoy with negative residuals in the regression model (respectively as $-1.07,-1.21$, and -1.88 ), overestimate the role of independent variables in the variance of number of construction firms. Besiktas and Bakirkoy, which are central district with high urban density and high housing price values (Koramaz and Dokmeci, 2012), have a common type of regeneration only on property-based renewal, in the last decade, after the law of 6306 (Kisar Koramaz, et. all, 2018). As indicated in Fig. 1, Basaksehir is one of the significant district with highest construction size in building permits in 2019, the district is is one of a leading sub-market associated with increased housing supply for middle and middle-high income households. These findings indicate that recent regeneration programs and urban transformation trends, particularly on area-based renewal programsin district level should be investigated in the further analyses of spatial distribution of construction firms in Istanbul. 


\section{Conclusion and Evaluation}

In this study, overall results from the multiple regression model indicate that the role of socioeconomic indicators and total size of construction in building permits is proved on a large scale, with the chosen variables in this paper, combined with population size of the districts. The spatial distribution of the construction firms has been figured out that the sub-central and peripheral districts of Istanbul have sustained the significant role in a way that responds to the construction supply. However, the intense construction demands in the periphery reveal a trend that these companies preserve the location of their management offices in the sub-centre with relatively higher economic attraction. With these concluding remarks, it is obvious that this paper, which examines the distribution of construction firms at the district level in Istanbul, validates the decentralization evidence from the findings of the literature on the housing market in Turkey and in the World.

Particularly urban renewal and construction activities, the intensity of which has increased enormously in the last 10 years, have caused a consecutive increase in the number of construction companies and enlargement of construction-based entrepreneurs. As in the Fikirtepe Urban Renewal Project (Turk et al., 2020) in Kadıköy, the extravagant size of the urban renewal areas has led to the authorization of many construction firms in the redevelopment of the city. However, the involvement of newly founded and unreliable construction firms with limited human and capital resources in the renewal (and construction) operations can make these firms be considered in low reputation in public opinion. In this study, construction firms, enrolled in the Istanbul Chamber of Commerce were selected. It should be noted that just as these firms benefit from the opportunities of being under an organization, they could eliminate such reliability problems in public opinion. While some of the construction companies that take part in construction projects carried out in public-private cooperation can ignore social priorities (Unsal and Turk, 2014), others may misuse their positions in negotiation and communication processes in a way that threatens the community. (Ay, 2019).

The findings of this paper explain the need to examine the spatial distribution of construction permits at a more detailed level. A further paper can highlight the central districts and sub-zones of the city, which are especially densely built, and where this construction has reached its development capacity. However, it should be taken into account that the construction processes mentioned with the urban renewal programs and the development plans for these central districts may enter a new cycle. Therefore, with the evaluation made as to the center, buffer zone, and periphery in this study, both the construction trends and the role of the sector, itself, in the spatial organization can be explained with a robust model in further studies. The findings of this paper, in a descriptive manner, can distinguish centers that are potential renewal areas, fulfilling development capacity, but housing sub-markets can be defined with a detailed model in such further studies. Moreover, this classification, itself, can be associated with the varying urban renewal phase of districts and be subjected to a temporal evaluation.

The findings of this paper can increase the ability of construction businesses to make rational site selection decisions, as well as has contributed, from the perspective of urban planning to the comprehension of urban development and sprawl patterns. The overlapping finding of the decentralization of the construction firms and the rapid urban sprawl is a fact to be taken into account in the future of plan-making decisions. Apart from the companies enrolled in the Istanbul Chamber of Commerce, it would be worthy to carry out further studies to examine the other components of the construction sector serving in the city. The distribution of organized and unorganized firms is thought to be illuminating in the description of the planned growth model of the city. 


\section{References}

Adams, D., Leishman, C., and Watkins, C., (2012) 'Housebuilder, networks and residential land markets', Urban Studies, 49(4), 705-720.

Alkay, E., Watkins, C., \& Keskin, B. (2018). Explaining spatial variation in housing construction activity in Turkey. International Journal of Strategic Property Management, 22(2), 119-130.

Ay, D. (2019). Diverging community responses to state-led urban renewal in the context of recentralization of planning authority: an analysis of three urban renewal projects in Turkey. Habitat International, 91, 102028.

Business Demography, 2019, Turkish Statistical Institute, retrieved from https://biruni.tuik.gov.tr/medas/?kn=145\&locale=tr, accessed date, 18 April 2021.

Baycan-Levent, T. and Gulumser, A. (2012) Gated communities in Istanbul: The new walls of the city,Town Planning Review, 83(1), 87-109.

Berkoz, L. (2000)'Location of financial, insurance and real estate firms in Istanbul,' Journal of Urban Planning and Development, 126(2), 175-88.

Berkoz, L. and Turk, S.S. (2008) 'Determination of location-specific factors at the intra-metropolitan level: Istanbul case,' Tijdschrift voor economische en sociale, 99(1), 94-114.

Chia, F.C., Skidmore, M., Runesan, G., Bridge, A. (2014) 'Construction Management and Economics, 32(9), 874-87.

Dokmeci, V.and Berkoz, L. (1994) 'Transformation of Istanbul from a monocentric to a polycentric city, European Planning Studies, 2(2), 193-205.

Dokmeci, V. and Berkoz, L. (2000) 'Residential-location preferences according to demographic characteristics in Istanbul, Landscape and Urban Planning 48(1-2), 45-53.

Duman, D.U., Green, S.D., Larsen, G.D. (2018) 'Historical narratives as strategic resources: Analysis of the Turkish international contracting sector,' Construction Management and Economics, 37(7), 367-383.

Dunning, J. and Morgan, V. E. (eds.) (2013) An Economic Study of the City of London, London: Routledge.

Hepsen, A., and Vatansever, M. (2012). Using hierarchical clustering algorithms for Turkish residential market. International J. of Economics and Finance, 4(1), 138-150.

Hurriyet News (2018) Istanbul emlak sektöründe zirveye oynuyor,' retrieved from https://www.hepsiemlak.com/emlak-yasam/haberler/istanbul-kadikoy-emlak-sektorunde-zirveyeoynuyor, accessed date 06.7.2018.

Istanbul Metropolitan Municipality, Open Data Portal, 2018, District-Based Average Household Size in 2018, retrieved from https://data.ibb.gov.tr, accessed date, accessed date 18 April 2021.

Karaman, O. (2008) "Urban pulse- (Re) Making space for globalization in Istanbul," Urban Geography 29(6), 518-525.

Kisar Koramaz, E., Koramaz, T. K., \& Ozer, O. (2018). Urban transformation through property-led regeneration: A case of building renewals in İstanbul. A IZ ITU Mimarlık Fakültesi Dergisi, 15(2), 183-196.

Koramaz, K. and Dokmeci, V. (2012) 'Spatial determinants of housing price values in Istanbul, European Planning Studies, 20(7), 1221-1237.

Kaynak, E. and Dalgic, T. (1992) Internationalization of Turkish construction companies: A lesson for Third World Countries? The Columbia J.ournal of World Business, 27(4), 60-75.

Kuyucu, T. and Unsal, O. (2010) Urban transformation as state-led property transfer: an analysis of two cases of urban renewal in Istanbul, Urban Studies 47(7), 1479-99.

Maoh, H. and Kanaroglou (2007) 'Geographic clustering of firms and urban form: A multivariate analysis,' Journal of Geograph Systems, 9(1), 29-52.

Nahm, K.-B. (1999) 'Downtown office location Dynamics and transformation of central Seoul, Korea, Geojournal 49(3), 289-299.

Noel, N. M., \& Luckett, M. (2014). The benefits, satisfaction, and perceived value of small business membership in a chamber of commerce. International Journal of Nonprofit and Voluntary Sector Marketing, 19(1), 27-39.

Ozus, E., Dokmeci, V. and Kiroglu, G. (2007) 'Spatial analysis of residential prices in Istanbul,' European Planning Studies, 15(5), 707-721.

Ozus, E. (2009) 'Determinant of office rents in the Istanbul Metropolitan Area, European Planning Studies, 17(4), 621-633.

Said, I., Osman, O., Rashideen, W., Shafiei, M. (2015) Proposed Conceptual model of Construction Firms' Performance Sustainability Indicators in Malaysia, Penerbit USM. 
Seker, M, et. all (2017) Mahallem Istanbul Project, retrieved from https://www.posta.com.tr/iste-istanbulun-en-zengin-ilceleri-istanbul-da-ilcelere-gore-gelir-dagilimi-haber-fotograf-1359815-1, accessed date 21 April 2020.

Terzi, F. and Bolen, F. (2009)' Urban sprawl measurement of Istanbul, European Planning Studies, 17(10), 1559-1570.

Turk, S. S., Tarakci, S., \& Gürsoy, N. (2020). A large-scale urban renewal project in a vicious cycle of commons and anticommons: The Fikirtepe case (Istanbul, Turkey). Habitat International, 102(2020), 102209, pp.113.

Unsal, F., and Turk, S.S. (2014) Legal and Institutional Context of Urban Planning and Urban Renewal in Turkey: Thinking on Istanbul, in Erkut, G. and Shirazi, M.R., (eds) Dimensions of Urban Redevelopment, Technische Universität Berlin Facultät VI-Planen Bauen Umwelt, pp.15-30.

Yazgi, B., Dokmeci, V., Koramaz,T.K., Kiroğlu, G. (2014) 'Impact of characteristics of origin and destination provinces on migration: 1995-2000,' European Planning Studies, 22(6), 1182-1198.

\section{Resume}

Prof. Dr. Turgay Kerem Koramaz, he has highlighted information and communication technologies, spatial analysis and modelling in urban planning, leading to publications on the subjects of cultural heritage management, spatial determinants of housing property prices, locational pattern of cultural venues, and internal migration patterns, in Turkey. Next to developing evidence-based decision-making processes in urban planning, methodological framing and information system, he has been involved in professional activities and consultancies in planning agencies and institutions. He is member of European Regional Science Association, ICOMOS, International Council on Monuments and Sites, and AESOP, Association of European Schools of Planning.

Prof.Dr. Vedia Dökmeci is a professor emeritus of Istanbul Technical University, Faculty of Architecture, Urban and Regional Planning Department. Dr. Dökmeci has many publications, 7 books and was involved in numerous professional activities, including design competitions, research projects, and fellowships, many of which intersected urban and environmental planning. In 2001 she established Real Estate Development Master Program at Istanbul Technical University. 